\title{
Critical Thinking in the EFL Context of Iran
}

\author{
Mansoor Fahim \\ Department of Foreign Languages and Literature, Allameh Tabataba'i University, Southern Allameh st., Tehran, Iran \\ E-mail: dr.manfahim@yahoo.com \\ Atefeh Rezanejad (Corresponding author) \\ Department of Foreign Languages and Literature, Allameh Tabataba'i University, Southern Allameh st., Tehran, Iran \\ E-mail: rezanejad_a85@yahoo.com
}

Received: 05-02-2014

doi:10.7575/aiac.ijalel.v.3n.4p.128
Accepted: 20-03-2014

Published: 01-07-2014

URL: http://dx.doi.org/10.7575/aiac.ijalel.v.3n.4p.128

The function of education is to teach one to think intensively and to think critically. Martin Luther King Jr.

\begin{abstract}
Critical thinking defined as the ability to think about your own thinking with a more analytical perspective, has long been an important side of education history. Recently there has been much attention devoted to this concept, particularly in the domain of language education. The present study is a review of the literature and previous studies done on the issue of critical thinking. In the first section an introduction to the study is presented. In the next section, the definitions of the notion of critical thinking from different scholars are put forth. In the third part, we discussed the features and characteristics of a real critical thinker. In the fourth part, the idea of teachability of critical thinking is discussed. It is tried to present some strategies which can enhance critical thinking in students.
\end{abstract}

Keywords: critical thinking, attributes, education

\section{Introduction}

Recently, more and more emphasis is put on the importance of critical thinking skills in the field of education. It is believed that these skills are of significance to the success of the learners. Unlike the previous popular trends in educational contexts, nowadays the learners are encouraged to inquire about the validity and truth of ideas, challenge and question them, strive for their own opinions, argue over different types of knowledge through reasoning and logic, and in essence seek scientific, reflective, logical, and critical thinking instead of non-scientific, intuitive, illogical thinking.

As Thomas \&Smoot (1994) and Huitt (1998) stated, critical thinking is a very vital factor of education in the $21 \mathrm{st}$ century. In addition, as Rezaei, Derakhshan, and Bagherkazemi (2011) stipulate, in the age of information, in which good thinking skills are necessary in order for success in life to happen, new strategies such as critical thinking skills need to be focused more in the educational contexts. They continue that "old standards of simply being able to score well on a standardized test of basic skills, though still appropriate, cannot be the sole criterion based on which to judge the academic success or failure of students" (p. 769).

\section{What is critical thinking?}

Reviewing the literature on the definition of the term critical thinking reveals that it is very difficult to come up with a unitary and well-accepted definition of the term. In the same lines, Halanon (1995) states that "critical thinking scholarship is in a mystified state. No single definition of critical thinking is widely accepted" (p. 75). In addition, Minnich (1990) affirms that critical thinking is a "mystified concept" (p. 5). Fasko (2003) and Huitt, (1998) also assert that there is no agreement on a definition of the phrase critical thinking. Siegel (1988) as well points out that "despite widespread recent interest in critical thinking in education, there is no clear agreement concerning the referent of the term" (p. 5).

According to Reed (1998), the term "critical thinking" is a broad concept which has attracted various different definitions by different scholars. He goes on saying that this lack of agreement in the proposed definitions is the results of the involvement of diverse theories and models from the two disciplines of psychology and philosophy. Whereas the field of philosophy has focused on the nature, origins, and outcomes of critical thinking, psychology has concentrated on processes of cognition and critical thinking. But the point is that, there are still some (Kuhn, 1999; Kurfiss, 1988; Marzano et al., 1988) who believe in adopting views from both psychology and philosophy in order to come about a legitimate and acceptable definition of critical thinking to be used for teaching purposes.

As a very rudimentary definition, it can be said that, critical thinking is adopting a questioning and challenging approach toward the acquired knowledge. Within the process of critical thinking, one examines ideas and information more deeply from an objective point of view and questions them in relation to his/her ideologies, philosophies, and 
ideas. In fact, critical thinking is the ability to think about your own thinking. In so doing, one needs to further reorganize one's strengths and weaknesses.

Dewey (1933, p. 118) defines critical thinking as "active, persistent, and careful consideration of any belief or supposed form of knowledge in the light of the grounds that support it and the further conclusions to which it tends". Also Pithers and Soden (2000) enumerate a number of skills and abilities necessary for a critical thinker. These abilities consist of identifying the problem and its fundamental assumptions, having a focused view on the problems, making an effort to analyze it and using inferences, using different types of logic (like deductive and inductive), judging on the validity of the assumptions besides the original sources of information and data.

Moreover, according to Chafee (1988, p. 29) critical thinking is "our active, purposeful, and organized efforts to make sense of our world by carefully examining our thinking, and the thinking of others, in order to clarify and improve our understanding". Also, as Facione (2006) puts it, critical thinking includes the elements of interpretation, analysis, evaluation, inference, explanation, and self-regulation. Fahim and Teimourtash (2012) refer to critical thinking as one of the major concepts which is paid lots of attention in current educational programs. As Halpern (1999) puts it "The ability to judge the credibility of an information source has become an indispensable Critical Thinking skill that needs to be deliberately and repeatedly taught in college and earlier" (p. 71).

Paul (1994) distinguishes between weak and strong forms of Critical Thinking. As he argues, weak critical thinking skills refer to a mere learning of the skill. However, the strong version of critical thinking maintains that these learned skills are actually put into practice and are exercised by individuals. Paul (1985) also defines critical thinking as "learning how to ask and answer questions of analysis, synthesis, and evaluation" (p. 37). Along the same lines, Brookfield (1987) believes that critical thinking entails two processes which are interrelated: "identifying and challenging assumptions, and imagining and exploring others" (p.229).

Halpern (2003) defines critical thinking as "the use of those cognitive skills or strategies that increase the probability of a desirable outcome ... thinking that is purposeful, reasoned, and goal directed" (p. 6). In another definition critical thinking is defined as the "reflective thinking involving the evaluation of evidence relevant to a claim so that a sound conclusion can be drawn from the evidence" (Bensley, 1998, p. 5). Diestler (2001) regards critical thinking as "the use of specific criteria to evaluate reasoning and make decisions" (p. 2). Along the same lines, Levy (1997) defines critical thinking as "an active and systematic cognitive strategy to examine, evaluate, understand events, solve problems, and make decisions on the basis of sound reasoning and valid evidence" (p. 236).

Further, Buskist and Irons (2008, p. 50) assert that critical thinking a very complex term to be defined. Still they stipulate that it would consist of some sub skills and subtasks such as: "a) Developing a skeptical approach to problem solving and decision making; b) Breaking down problems into their simplest outcomes; c) Searching for evidence that both supports and refutes a given conclusion; d) Maintaining a vigilant attitude toward their personal bias, assumptions, and values that may interfere with making an objective decision".

As Bassham, Irwin, Nardone, and Wallace (2011, p. 2) put it "critical thinking is disciplined thinking governed by clear intellectual standards". In their book titled as "Critical Thinking: A student's Introduction", they mentioned eight elements and standards of a critical thinker. They include:

\section{Clarity}

It is argued that before we can effectively evaluate a person's dispute or assert, a necessary requirement is to realize without a doubt what he or she is actually saying. However, unfortunately it seems that this is mostly difficult because many can't get their messages across because of some reasons such as laziness, carelessness, or insufficient skills. "Critical thinkers not only strive for clarity of language but also seek maximum clarity of thought". Such clarity of thought will lead to self-understanding, goal-setting, realistic view toward abilities, and success in life.

\section{Precision}

The significance of precision is highly recognized in such fields of studies as medicine, mathematics, architecture, and engineering. But the point is that, more specifically, critical thinkers recognize the weight which should be attributed to precise and accurate thinking in their everyday life. "They understand that to cut through the confusions and uncertainties that surround many everyday problems and issues, it is often necessary to insist on precise answers to precise questions ... Only when we habitually seek such precision are we truly critical Thinkers." Critical thinkers try to figure out the exact problem, alternatives, and also pros and cons of each alternative.

\section{Accuracy}

"Critical thinkers don't merely value the truth; they have a passion for accurate, timely information. As consumers, citizens, workers, and parents, they strive to make decisions that are as informed as possible".

\section{Relevance}

This issue refers to the pertinence of talks when discussing a topic. Critical thinkers don't try to evade the issue by raising irrelevant topics. But they try to keep the element of relevance when dealing with different topics.

\section{Consistency}

As one of the other standards of critical thinking, it is stated that critical thinkers look for consistency in what they say and do. The two kinds of inconsistency that the authors mentioned included: "logical inconsistency, which involves 
saying or believing inconsistent things (i.e., things that cannot both or all be true) about a particular matter. The other is practical inconsistency, which involves saying one thing and doing another".

\section{Logical Correctness}

"To think logically is to reason correctly - that is, to draw well-founded conclusions from the beliefs we hold. To think critically we need accurate and well-supported beliefs." More important than that, it was argued that being able to reason from beliefs and then reaching conclusions is one of the leading features of critical thinkers.

\section{Completeness}

As a general rule, deep and thorough thinking is better than shallow and superficial thinking. Completeness is in fact one of the features of deep thinking. Some even don't consider a shallow thinking as a real process of thinking.

\section{Fairness}

As a final element the authors talked of fairness. They argued, "Critical thinking demands that our thinking be fairthat is, open-minded, impartial, and free of distorting biases and preconceptions."

\section{Who is a critical thinker?}

Chance, (1986, cited in Fahim, Miri, \& Najafi, 2014) defined critical thinking as "the ability to analyze facts, generate and organize ideas, defend opinions, make comparisons, draw inferences, evaluate arguments and solve problems" (p. 6). Nevertheless, to see who is a critical thinker, it might be helpful to notice who might not be a critical thinker. The uncritical thinker is often "unclear, imprecise, vague, illogical, unreflective, superficial, inconsistent, inaccurate, or trivial" (Paul, 1990, cited in Fahim \& Ahmadian, 2012, p. 795). He further stipulated that

"a critical thinker is someone who has an understanding of and an ability to formulate, analyze, and assess: 1 . The problem or question at issue; 2 . The purpose or goal of the thinking; 3 . The frame of reference or points of view involved; 4. Assumptions made; 5. Central concepts and ideas involved; 6. Principles or theories used; 7. Evidence, data, or reasons advanced; 8. Interpretations and claims made; 9. Inferences, reasoning, and lines of formulated thought; and 10. Implications and consequences which follow. (p. 795)".

Reviewing the literature on the topic of critical thinking (e.g. Bensley, 1998; Birjandi \& Bagherkazemi, 2010; Diesther, 2001; Fisher, 2001; Halpern, 2003; Levy, 1997; Rezaei, Derakhshan, \& Bagherkazemi, 2011) illustrates that critical thinkers are those who:

- try to think about substitute explanations for different states;

- restrain from showing any emotional reactions to arguments between others;

- are strongly determined to be acquainted with the significance of good thinking;

- can easily recognize problems and focus solely on the pertinent topics and issues;

- can make a distinction between valid and invalid inferences;

- are careful about the impact of authorities and baseless arguments;

- try to predict the outcomes of different actions;

- precisely make clear their decisions;

- establish the truth or falseness of assumptions;

- postpone conclusions and decisions when adequate evidence is not present;

- comprehend the distinction between logical reasoning and rationalizing;

- are attentive of the point that one's understanding is restricted and that belief has some degrees;

- are able to make a distinction between plausible and non-plausible sources of information;

- set apart evidence from opinion, common sense, and anecdotes;

- can listen thoughtfully to others and provide them with appropriate comment;

- can judge and evaluate different statements told by others;

- are very curious to know more;

- can even judge themselves and their behavior;

- make a clear distinction between chief and minor sources of information and are sensitive to them;

- tell apart opinions from facts and do not treat them the same way;

- are so longing to prove statements;

- accept criticisms and welcome them;

- devise and inquire suitable types of questions;

- collect data from numerous sources which are related to a problem in order to solve it;

- can infer inferences from the situation they are in.

In the same lines, Carroll (2004) believes that

The critical thinker will be a better problem-solver and better decision-maker. When we're thinking critically, we're using our knowledge and intelligence effectively to arrive at the most reasonable and justifiable position possible. When we're thinking uncritically - no matter how intelligent or knowledgeable we are - we'll make unreasonable decisions and arrive at unreasonable beliefs or take unjustifiable actions, unless we are lucky and end up making the right choice for the wrong reasons! (p. 2) 
Brookfield (1987) believes that critical thinking covers two interconnected processes. They include: "identifying and challenging assumptions, and imagining and exploring others" (p. 229). Brookfield (1987) further mentions a number of more features for real critical thinkers. It is supposed that they are involved in productive and positive activities, and also dynamically involved with life. What is more, they identify themselves as creative and inventive in various phases of their personal lives. Additionally, it's interesting that critical thinkers view their thinking as a process and procedure, rather than an ending product; they are constantly questioning the reality and authenticity of assumptions since critical thinking is not a fixed phenomenon.

As King (1995) believes, a critical thinker has an "inquiring mind". Good critical thinkers, unlike poor ones, are good at asking questions and inquiring about different topics. They are always analyzing whatever they see, hear, read, or write and question their significance, validity, and reliability.

\section{Some recent studies done on the concept of critical thinking in the EFL context of Iran}

Izadinia and Abednia (2010) investigated the dynamics of an EFL reading course with a critical literacy orientation. They mainly wanted to explore whether a critical literacy $(\mathrm{CL})$ approach to teaching reading may possibly contribute to EFL learners' personal development and their insight toward a reading course. The participants of their study were 25 B.A. English Literature students from one of the universities in Iran. The students were encouraged to deal with the reading passages by group discussions and reflective journals. In order to explore the results, two self-assessments and two class assessments were collected from the students at the end of the term. The results indicated that the course could improve the critical thinking skill of the students. For example it was observed that there were developments in voice and self-awareness.

Fahim, Bagherkazemi, and Alemi (2010) tried to examine to what extent the standardized test of TOEFL can engage the critical thinking skills of the participants. In their study, 83 advanced EFL learners took part. First of all they completed the Watson-Glaser Critical Thinking Appraisal (1980). Later, the results of the critical thinking questionnaire were correlated with the scores of the students on the reading section of Paper-Based TOEFL (PBT). The results of the study showed that there was a statistically significant relationship between the two tests and those with greater critical thinking skills over performed those with lower skills.

In another study entitled "The Impact of Teaching Critical Thinking Skills on Reading Comprehension of Iranian EFL Learners", Fahim and Sa'eepour (2011) investigated the impact of teaching critical thinking skills on the reading comprehension ability of the students and also the influence of the use of debate in classrooms on the critical thinking skill of the EFL learners. The sixty participants of this study were divided into two groups of experimental and control. According to the researchers, the experimental group received 8 sessions of treatment (using debate as a classroom activity). The analysis of the collected data through the pre test and post test showed significant differences. The results indicated that teaching critical thinking skills in EFL context can further lead to improvements in language learning.

To enlarge the literature, some additional research was performed by Khatib, Marefat and Ahmadi (2012) to compare two kinds of pedagogical techniques used in EFL classrooms in order to explore the effect audiotaped and written dialogue journals on the enhancement of critical thinking among EFL students. 33 Iranian EFL learners in 3 intact classes took part in this research study. The researchers adopted a pretest-posttest design. The Watson-Glaser Critical Thinking Appraisal was given to the students as pretest. Two different experimental groups adopted two different kinds of dialogue journals i.e. audiotaped or written and the control group did the usual writing tasks. Finally, at the end of the semester, a post test was given to the students. The results depicted that there was a significant difference between the two groups. The researchers concluded that explicit ways of teaching critical thinking can have a significant effect on the improvement of this skill among the EDL learners.

In an interesting study, regarding the viewpoint taken, Fahim and Teimourtash (2012) made an effort to take a critical look at the concept of critical thinking from the "Midtrovert Personality Trait Perspective". The new area which the authors have named "Midtrovert", entails the area in which "the learners are led to participate and engage in the oscillating process of learning and as a result, leave so much room for the teachers to maneuver in the zone and promote the critical thinking level of the learners from low critical thinkers to high critical ones" (p. 149). The authors believe that "an Introvert learner does not really exist in reality because the Introvert learner would never ever attend any (language) classes and avoid any open gathering in publicity. Of course such Introvert individual is the absolute Introvert in authors view. The same is true with the other end of the extreme as the Extrovert that such an individual does not exist in reality, because the Extrovert learner to its absoluteness and extremeness has a magical standing point due to being involved in a dynamic and diachronic zone. The authors believe that an act of oscillation in the zone of proximal critical thinking which authors called the involved learners as "Midtrovert" personality trait is the key to promote the critical thinking level of the learners" (Fahim \& Teimourtash, 2012, p. 149).

Hashemi and Zabihi (2012) explored the effect of Iranian EFL learners' critical thinking abilities on their receptive language skills. The Persian version of Watson-Glaser Critical Thinking Appraisal (WGCTA) and the Interchange Objective Placement Test (Lesley, Hansen, \& Zukowski-Faust, 2005) was administered to 96 Iranian Intermediate EFL learners. The scores on the two tests were correlated to discover any significant relationship between critical thinking and language proficiency. At the end, the researchers reported significant correlations between WGCTA test and proficiency scores of the learners. 
In a most recent study, Fahim, Miri, and Najafi (2014) explored the relationship between enhancing critical thinking skills and improving second language writing skills. They specifically investigated the role of collaborative assessment in promoting critical thinking and second language writing skill. In this study, two intact classes were exposed to the two forms of Student-Student and Teacher-Student collaborative assessments through six sessions of treatment. Results of the study depicted that collaborative assessment (either type), has the possible capability to encourage critical thinking and writing proficiency. Further, the results showed that Student-Student collaborative assessment group significantly outperformed the other group (Teacher-Student collaborative assessment) in relation to levels in critical thinking and writing proficiency.

\section{Can critical thinking be taught? How?}

"The issue of incorporating critical thinking skills in education has raised many contradictory ideas about whether critical thinking can be taught or not" (Fahim \& Sa'eepour, 2011, p. 867). Many scholars consider critical thinking to be central to higher levels of education or a primary goal of learning (Kuhn, 1999; Keeley \& Shemberg, 1995). It seems that all research activities include some sort of critical thinking. Barnett (1997, p. 2) calls it a "defining concept of the Western university". Reed (1998) believes that thinking critically is the foremost objective of education. However, it seems that due to the difficulties teachers face in applying critical thinking to their classes, not all teachers are willing to teach critical thinking to their students. Buskist and Irons (2008, p. 53) mention some of these sources for the teachers' resistance to teaching students to think critically:

a) Academia can be a demanding and time-consuming profession that often requires a delicate balance of teaching, service, and research. When time is scarce, teaching preparation may take a back seat to other, more pressing, obligations. b) Some teachers may forego teaching critical thinking because they cannot easily measure the effects of their teaching efforts to show that it has been effective. As teachers, we often rely on grades as indicators that students have learned and that we have done our jobs. It is not as easy to assess critical thinking skills as typical course content, so that it may not be evident if students are learning the critical thinking skills we try to teach them. Developing ways to assess critical thinking is yet another demanding task to add to teachers' lists of daily chores. c) Because students often resent being urged to think critically and teachers want to be liked by students, some teachers may sacrifice critical thinking in their classes in exchange for popularity. d) Not all teachers are critical thinkers, and these teachers may not feel comfortable enough with their own skills to ask their students to think critically. Holding a master's degree or PhD does not guarantee that one can think critically. e) Many teachers may not know how to teach critical thinking skills, although they value those skills and wish for their students to become critical thinkers. (p. 53)

Buskist and Irons (2008) enumerate some different reasons for which teachers and students at schools may feel unwilling to think critically and teach critical thinking. We include some of them here:

a) it seems that some of the fact originates from other people important to the students; from some people like the parents, coach, and teachers. If they have too much authority and control on the students, this will lead to a discouragement of accepting critical thinking. That is mainly because these people always try to tell the students what to do and what not to do.

b) allowing others to make decisions for them will further lead to refraining responsibilities. The students will feel free to say that "Because somebody tells me what to do, and I do it, I should not be held account-able for my actions-I was just doing as I was told. (p. 52)".

c) another reason mentioned by the authors was related to the sociocultural values of the students. Due to their inherent beliefs, they may regard their beliefs as second-rate and inferior to the one made by those in authority. Some are even instructed to "obey the authority". This makes students believe that "I am not ready to make decisions on my own-I need to look to older, wiser, and more informed people to tell me what to do. (p. 52)".

d) unfortunately, many first and second year students are not able to think in terms of fuzzy logic. Everything is either black or white for them. There is no such concept as gray.

e) lots of students do not bother themselves to thinking about various issues taught to them. On the other hand, they just try to memorize them. "Memorizing facts and figures takes time and effort, to be sure, but it does not require the uncertainty that goes with thinking - and that uncertainty can be discomforting to some students. (p. 52)".

f) as some students are assured of having someone to protect them against the consequences of their decisions, they may not be that much aware of the outcomes of their wrong decisions. And further do not try to improve their decision making ability.

g) another important issue raised by the authors was related to the fact that some students don't really have any time deal with critical thinking. Besides the heavy loaded academic work, they may be forced to work outside in order to help the family on the financial issues.

h) the last reason was related to the insufficient academic knowledge of the students. It was argued that they may not have the basic necessary knowledge required for critical thinking.

Bassham, Irwin, Nardone, and Wallace (2011) raised an interesting question: If critical thinking is so important, why many find it very difficult to follow and don't pay enough attention to it? They went on and further proposed a list of reasons which may lead to this attitude. Some of them are as follows: 
a) not enough related background information

b) insufficient skill in reading

c) prejudice and bias in the attitudes of people toward different issues and being narrow-mindedness

d) superstitious beliefs toward facts and happenings

e) deceiving oneself and being afraid of change

Despite all these barriers, Buskist and Irons (2008) still suggest some ideas for teaching critical thinking:

a) For each and every core topic in your class, provide students with problems to analyze or solve. It doesn't matter whether you ask students to tackle these problems in or out of the class - the important thing is that they have the opportunity to think critically about them. b) Guide students in the development of their critical thinking skills with handouts (either paper or electronic) containing information about critical thinking techniques that you have found particularly effective in your quest to solve problems and make informed decisions (e.g., explain what it means to - consider alternative explanations\| or - weigh the evidencell or - determine the truth or falsity the assumptions\|). c) Take time in class to apply these methodologies to your subject matter so that you can model effective critical thinking for your students. Your teaching should provide your students with the opportunity to see critical thinking in action through a role model you! d) You should bring to class some of those everyday examples of critical thinking (or lack of critical thinking) that you've been collecting since before the academic term started. Make sure the examples are relevant to your subject matter. e) Give your students plenty of opportunity to practice their developing critical thinking skills, including examinations and other graded assignments. If you don't test it, many students won't study it. Besides, it makes good sense to test students on those key elements of the course that you stress as important - in other words, you should put your money where your mouth is! (p. 56).

In the same lines, Rezaei, Derakhshan, and Bagherkazemi (2011, p. 775) put forth some other techniques to be used as strategies for enhancing critical thinking in the students. They are as follows:

a) Debate/Forum/Discussion: they argued that as debates are flexible and consequential in the range of topics and the format, they can motivate students' enthusiasm to critically contemplate upon topics from different perspectives.

b) Media Analysis: Considering the sociopolitical and cultural dimensions of critical thinking, they found media analysis quite advantageous in raising the students' awareness about issues such as equality, discrimination, bias, censorship, and marginalization.

c) Problem Solving Tasks and Activities: Group discussions are encouraged so that the students can develop the ability of critical thinking. Students in groups need to describe the content of discussion, to define the problem, to personalize the problem, to discuss the problem and its alternative solutions, and finally to evaluate the whole process.

d) Self-assessment \& Peer-assessment Assignments: The writers stated that one way to improve the critical thinking skill of the students is to engage them in carefully guided self- and peer-assessment tasks. In order for the students to be successful critical thinkers, they should be given a chance to evaluate not only themselves but also others. (p. 775).

\section{Conclusion}

As Pennycook (1990) observes, only critical pedagogy can save language education from the seemingly separation from its educational side and extreme devotion to the linguistic side. This paper made an effort to offer an in-depth review of literature on the concept of critical thinking and its applications in language classes. The present review seemed to corroborate what Izadinia and Abednia (2010) asserted as "... there is no single version of critical pedagogy out there to be discovered and adhered to, but critical pedagogies must be co-constructed by human beings" (p. 65). Alongside with the existing literature, it is highly recommended that EFL teachers be experts in critical pedagogy themselves, and also encourage their students to be critical thinkers. Students need to be trained and helped to acquire critical thinking skills and adopt a critical approach toward solving problems and challenges in language classes. In terms of classroom teaching some techniques can smooth the progress of developing critical thinking skills. For instance, as a good strategy, teachers need to take advantage of asking questions during class time, involving the students in challenging discussions on new, interesting, and motivating topics, and engaging the students in the processes of the education. Moreover, to enumerate some practical techniques to enhance critical thinking skills of the students, we can mention use of debates and problem-solving tasks (Rezaei, Derakhshan, \& Bagherkazemi, 2011) along with exploiting self-assessment and peer-assessment tasks during class works.

\section{References}

Barnett, R. (1997). Higher Education: a critical business. Milton Keynes: SRHE and Open University Press.

Bassham, G., Irwin, W., Nardone, H., \& Wallace, J. M. (2011). Critical Thinking: A student's Introduction. New York: Mc Graw-Hill.

Bensley, D. A. (1998). Critical thinking in psychology: A unified skills approach. Pacific Grove, CA: Brooks/Cole.

Birjandi, P. \& Bagherkazemi, M. (2010). The relationship between Iranian EFL teachers' critical thinking ability and their professional success. ELT, 3(2), 135-145.

Brookfield, S. (1987). Developing critical thinkers. Milton Keyes: Open University Press. 
Buskist, W. \& Irons G. J. (2008). Simple strategies for teaching your students to think critically. In D. S. Dunn, J. S. Halonen, and R. A. Smith (Eds), Teaching Critical Thinking in Psychology: A Hand book of Best Practices (pp.4957). UK: Blackwell Publishing Ltd.

Carroll, R. T. (2004). Critical thinking. Retrieved in 2012, March, from http://www.scribd.com/doc/16426858/Critical-Thinking-Ch1-Drrobert-Todd-Carroll

Chaffee, J. (1988). Thinking critically. Boston, MA: Houghton Mifflin.

Dewey, J. (1933). How we think: A restatement of the relation of reflective thinking to the educative process. Boston: D.C. Heath.

Diestler, S. (2001). Becoming a critical thinker: A user friendly manual (3rd ed.). Upper Saddle River, NJ: PrenticeHall.

Facione, P. (2006). Critical thinking: What it is and why it counts. California: California Academic Press.

Fahim, M., \& Ahmadian, M. (2012). Critical Thinking and Iranian EFL Context. Journal of Language Teaching and Research, 3(4), 793-800.

Fahim, Bagherkazemi, \& Alemi (2010). The relationship between test takers critical thinking ability and their performance on the reading section of TOEFL. Journal of Language Teaching and Research, 1(6), 830-837.

Fahim, M., \& Sa'eepour, M. (2011). The impact of teaching critical thinking skills on reading comprehension of Iranian EFL learners. Journal of Language Teaching and Research, 2(4), 867-874.

Fahim, M. \& Teimourtash, M. (2012). A critical look at the notion of critical thinking from a new personality trait perspective: "Midtrovert". Advances in Digital Multimedia, 1(3), 149-152.

Fahim, M., Miri, M., \& Najafi, Y. (2014). Contributory role of collaborative assessment in improving critical thinking and writing. International Journal of Applied Linguistics \& English Literature, 3(1), 1-11.

Fasko, D. (2003). Critical thinking: Origins, historical development, future direction. In D. Fasko (Ed.), Critical thinking and reasoning: Current research, theory and practice (pp. 3-20). Cresskill, NJ: Hampton Press.

Fisher, A. (2001). Critical thinking: An introduction. New York: Cambridge University Press.

Halpern, D. F. (1999). Teaching for critical thinking: Helping college students develop skills and dispositions of a critical thinker. New Directions for Teaching and Learning, 80, 69-74.

Halpern, D. F. (2002). Teaching for critical thinking: A four-part model to enhance thinking skills. In S. F. Davis \& W. Buskist (Eds.), The teaching of psychology: Essays in honor of Wilbert J. McKeachie and Charles L. Brewer (pp. 91-105). Mahwah, NJ: Lawrence Erlbaum Associates.

Halpern, D. F. (2003). Thought and knowledge: An introduction to critical thinking (4th ed.). Mahwah, NJ: Erlbaum. Halonen, J. S. (1995). Demystifying critical thinking. Teaching of Psychology, 22, 75-81.

Hashemi, M. R., \& Zabihi, R. (2012). Does critical thinking enhance EFL learners' receptive skills?. Journal of Language Teaching and Research, 3(1), 172-179.

Huitt, W. (1998). Critical thinking: An overview. Educational Psychology Interactive. Retrieved March, 2009, from http://chiron.valdostaedu/whuitt/col/cogsys/critthnk.html. [Revision of paper presented at the Critical Thinking Conference sponsored by Gordon College, Barnesville, GA, March, 1993.]

Izadinia, M. \& Abednia, A. (2010). Dynamics of an EFL reading course with a critical literacy orientation. Journal of Language and Literacy Education, 6(2), 51-67.

Keeley, S. \& Shemberg, K. (1995). Coping with student resistance to critical thinking. College Teaching, 43(4), 140147.

Khatib, M., Marefat, F., \& Ahmadi, M. (2012). Enhancing critical thinking abilities in EFL classrooms: Through written and audiotaped dialogue journals. Humanity \& Social Sciences Journa,l 7(1), 33-45.

King, A. (1995). Inquiring minds really do want to know: Using questioning to teach critical thinking. Teaching of Psychology.

Kuhn, D. (1999). A developmental model of critical thinking. Educational Researcher, 28(2), 16-26.

Kurfiss, J. G. (1988). Critical thinking: Theory, research, practice, and possibilities. ASHE-ERIC Higher Education Report No. 2, 1988. ASHE-ERIC Higher Education Reports, The George Washington University, One Dupont Circle, Suite 630, Dept. RC, Washington, DC 20036-1183.

Levy, D. A. (1997). Tools of critical thinking: Metathoughts for psychology. Boston: Allyn \& Bacon.

Marzano, R. J., Pickering, D., Arredondo, D. E., Blackburn, G. J., Brandt, R. S., \& Moffett, C. A. (1992). Dimensions of learning. Association for Supervision and Curriculum Development.

Minnich, E. (1990). Transforming knowledge. Philadelphia: Temple University Press.

Paul, R. W. (1985). Bloom's taxonomy and critical thinking intervention. Educational Leadership, 42(8), 36-39. 
Paul, R. W. (1990). Critical thinking: What every person needs to survive in a rapidly changing world. Retrieved June 2011 from www.amazon.com/Critical-thinking-survive-rapidly-changing/

Paul, R. W. (1994). Teaching critical thinking in the strong sense. In S. K. Wlaters (Ed), Re-Thinking Reason: New Perspectives in Critical Thinking (pp. 181-198). Albany: SUNY Press.

Pennycook, A. (1990). Critical pedagogy and second language education. System 18(3), 303-314.

Pithers, R. T., \& Soden, R. (2000). Critical thinking in education: A review. Educational Research, 42(3), $237-249$.

Reed, J. H. (1998). Effect of a model for critical thinking on students' achievement in primary source document analysis. (a PhD dissertation) University of south Florida. Retrieved March 28, 2008 from www.criticalthinking.org

Rezaei, S., Derakhshan, A., \& Bagherkazemi, M. (2011). Critical thinking in language education. Journal of Language Teaching and Research, 2(4), 769-777.

Siegel, H. (1988). Educating reason: Rationality, critical thinking and education. New York: Routledge \& Metheun. Thomas, G., \& Smoot, G. (1994). Critical thinking: A vital work skill. Trust for Educational Leadership, 23 , 34-38. 